\title{
Deafness, Autosomal Recessive 1A
}

National Cancer Institute

\section{Source}

National Cancer Institute. Deafness, Autosomal Recessive 1A. NCI Thesaurus. Code C129022.

An autosomal recessive disorder caused by mutations in the GJB2 gene, encoding gap junction beta- 2 protein. The condition is characterized by profound sensorineural hearing loss and may be associated with vestibular dysfunction. 